\title{
Approaching Laestadianism
}

DOI: https://doi.org/10.30664/ar.95047

(c) Attribution 4.0 International (CC BY 4.0)

$\mathrm{T}$

he Laestadian movement has, since it arose in the mid-and late 1800 s, become the largest Christian revival movement in Scandinavia. Today, however, the term 'Laestadian movement' in the singular is highly questionable. The core reference is to a conservative, evangelical Christian movement with its historical background in the revival instigated by the Swedish minister Lars Levi Laestadius (1800-61). All Laestadian groups today in some way or another refer to this common heritage.

The research on Laestadius, and especially on the Laestadian movement, has grown significantly in the past fifty years. For a long period, theology and church history were the academic disciplines dominating the research. In recent decades, more disciplines have contributed. Church history and theology are still the dominating disciplines in this research, but contributions from academic disciplines such as history, philosophy, political science, social anthropology, sociology and the study of religion have approached the man and the movement with research questions and the theoretical tools characteristic of each discipline. This is important in order to take the research further. Still, as indicated in the articles of Bengt-Ove Andreassen and
Rolf Inge Larsen in this issue, there are still Laestadian groups that are hardly covered in the research. Therefore, there is also still a need for empirical and historical research that helps to map and cover different groups' histories and identities.

There are, thus, different ways of approaching Laestadianism. The aim of this thematic issue on research on the Laestadian movement is to dwell with and look back on how the research on Laestadius and the Laestadian movement has developed, but at the same time show the latest developments in this research. In order to do so, we invited researchers from the Nordic countries to contribute to a thematic issue on research perspectives on the Laestadian movement. We wanted to present theoretical articles and research overviews in order to present updates and tendencies in the research about the Laestadian movement. The contributions are by Finnish and Norwegian scholars, and working on this special issue made us aware that the research activity on Laestadius and the Laestadian movement in Sweden, is currently very low. Hopefully, that will change in the near future. There are of course more researchers and research on Laestadius and the Laestadian movement than referred to and discussed in this special issue. 
The first article is Sandra WalleniusKorkalo's 'Care, longing, and control: representing corporeal Laestadianism in popular culture, in which she analyses how the Laestadian movement has been represented in different popular media in Finland. The article shows how theoretical developments concerning intersectionality and perspectives on religion and (popular) media contributes to the research on the Laestadian movement. WalleniusKorkalo's article should be an obvious inspiration for doing the same kind of analysis in a Norwegian and Swedish context. Anssi Ollilainen's article 'The Firstborn Laestadians and the sacraments: conceptual analysis as an approach to answering the question of why the Firstborn in Finland began administering the sacraments', provides insight to one of the latest developments in the Laestadian movement; namely a division among the Firstborns in Finland. In his article, Ollilainen discusses the concepts of the 'priesthood of all believers' and (the lay) 'preacher' and argues that these concepts help shed light on why the Firstborns broke with a long tradition when they began to administer the sacraments by themselves. Gerd Snellman offers a self-reflective discussion about doing research on the Laestadian movement as an insider in her article 'Approaching Laestadianism as an insider researcher'. Doing so, she enters an extensive methodological debate among social anthropologists and study of religion scholars. Snellman provides interesting examples of how she as an insider faces challenges and has access to data that other researchers do not.

Roald E. Kristiansen writes about the pictures that early scholarly work created of the Laestadian movement in his article entitled 'Depictions of Laestadianism 18501950'. Kristiansen argues that society's emerging view of the revival is characterized by two different positions in two different time periods. The first period (18501900 ) is characterised by an evaluation of the revival focused on Laestadius, and interprets the characteristics of the revival based on perceived personal shortcomings of Laestadius himself. In the second period (1900-50), Kristiansen argues, the views of Laestadianism are replaced with an 'exoticizing phase', characterized by an increased interest in and openness towards the revival as a phenomenon of the religious and cultural north. Rolf Inge Larsen's article 'A Research history of Laestadianism in Norway: from the 1960 s to the present day' introduces and discusses the history of research on Laestadianism in Norway over the last sixty years as offered in master's theses, journals, periodicals, and books on reminiscence or local history after 1960. Larsen provides an insight into the richness the research on the Laestadian movement has gained in Norway. However, Larsen also points to some 'holes' and challenges for this research. Larsen leaves out doctoral theses, which is the focus of Bengt-Ove Andreassen's article. Andreassen provides a review of all doctoral theses on Laestadius and the Laestadian movement in the period from 1937 (when the first doctoral thesis was handed in) until 2018. The article refers to thirty-one doctoral theses dealing with either Laestadius or the Laestadian movement. Finnish theses are by far dominant. Andreassen also shows that since the turn of the millennium, there have been more academic disciplines producing doctoral theses on Laestadius and the Laestadian movement. The approaches in the research on Laestadius and the Laestadian movement have thus been more varied.

The articles in this special issue illustrate that the research on Laestadius and the Laestadian movement is developing, in 
different ways. Still, the idea of this special issue was that it also might contribute to a process of self-reflection in the research on Laestadius and the Laestadian movement, as well as inspire more research.

\section{Bengt-Ove Andreassen, Roald E. Kristiansen and Rolf Inge Larsen Guest editors}

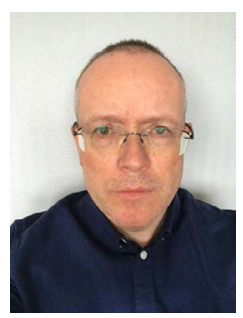

Bengt-Ove Andreassen, $\mathrm{PhD}$, is a full professor in the field of the study of religions at the Department of Education, UiT The Arctic University of Norway. His main areas of research are the didactics of religions (RE), religion in public education

and the Laestadian revival movement. Among his publications are Textbook Gods (ed. together with James R. Lewis, Equinox 2014), 'A review of theories on the Laestadian rørelse: on the academic construction of something extraordinary and exotic', in Acta Borealia, 34(1), 2017, pp. 70-89, and "Knowledge about religions" and analytical skills in religious education: reflections from a Norwegian context', in Center for Educational Policy Studies Journal - CEPS Journal, 9(4), 2019, pp. 73-90.

Roald E. Kristiansen, is an associate professor at the Department of Archeology, History, Religious Studies and Theology in UiT The Arctic University of Norway since 1997. He has an MA from Oslo University

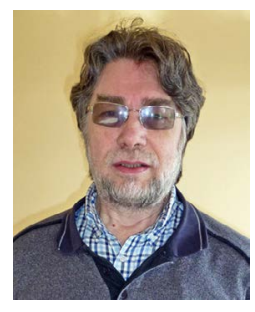
in theology (1979), and a PhD from Emory University in Atlanta, Georgia, USA, in constructive theology with a thesis on interfaith dialogue and theology (1987). He has been a visiting scholar at the National Council of Churches' study centre in Kyoto, Japan (1985/6), a seminary lecturer at the Methodist School of Theology in Bergen (1980-91), and associate professor at Finnmark University College (1991-7). Roald Kristiansen has published on interfaith theology, ecotheology, and contextual theology, as well as on Buddhism and Confucianism.
Rolf Inge Larsen is Associate Professor of History/History Didactics in UiT The Arctic University of Norway. His academic interests include Laestadianism, history

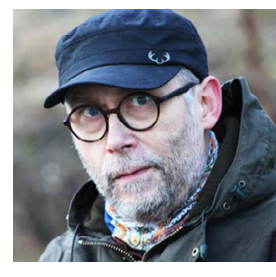
didactics and the uses of history. Among his recent publications are 'Minnehistorie og fortidsbruk. Minnene om han som tente lyset i Skibotn' (History and memory, and the use of the past: commemorations of he who lit the light in Skibotn) in Väckelser som minnes- och meningsskapande narrative, eds. Jakob Dahlbacka and Kim Groop (Åbo, 2017) and 'ABC-striden i Vadsø på 1880-tallet. Confessio Augustana og fornorskningspolitikken i skolen' (The ABC controversy in Vads $\varnothing$ during the 1880s: Confessio Augustana and the policy of Norwegianization in schools) in Historie - didaktik, dannelse og bevidsthed (Aalborg, 2017). 